\title{
EMPLOYEE AS A SUBJECT OF SUSTAINABLE MANAGEMENT
}

\section{Katarzyna Zadros}

University of Technology in Częstochowa, Poland

In modern companies, an employee is perceived as a particularly valuable asset whose importance increases as the company enters the path of sustainable development. This situation means that a new role is assigned to the employee, he becomes an element of human capital, or the intellectual capital of the organization; he is a stakeholder. What does this actually mean for companies and how can this situation be assessed from the employee's perspective? Does the concept of sustainable development influence changes in human resources management, and if so, in which areas are these changes visible in particular? Searching for the answers to these questions will be the goal of the article presented below.

Keywords: sustainable development, management, corporate social responsibility, employee

\section{Introduction}

Observing the Polish and international economies, it can be seen that companies are increasingly implementing and realizing the principles of sustainable and social responsibility development. In turn, there are studies on the implementation and realization of sustainable development, sustainable enterprises, sustainable management, sustainable marketing, sustainable production, and even sustainable personnel (Pabian, 2015) appearing in the literature referring to management and economics for a number of years. Does it mean that the economy and businesses have automatically begun to follow principles of "sustainability" in business practice? One can seriously feel doubtful about it (Hahn et al., 2018). It is difficult to assess in what degree employees participate in the implementation of such projects, and if they do participate, what benefits do they derive from it?

The aim of this paper is to find an answer to the following question what factors are decisive as far as the effective functioning of an employee in an enterprise operating in a sustainable manner is concerned and what factors are decisive as far as employee's usefulness for an enterprise is concerned.

A survey that will offer the answer to this question will be carried out on the basis of the analysis of Polish and international literature sources concerning these issues as well as the presentation of the results of the preliminary survey carried out on the basis of the analysis of companies' internal materials.

The notion of sustainable development has repeatedly been described in the national and international literature and United Nations (UN) and European Union (UE) documents. Its principles and methods, as well as measurement techniques and tools have been elaborated. When speaking of sustainable development, attention is paid to the fact that it constitutes the proposal of "a qualitatively new form of conscious and responsible individual and social life based on the development together with the environment social and natural taking into account environmental restrictions and social expectations" (Płaczek, 2012). In the UN Conference Declaration, it was defined as "development that meets the needs of the present without compromising the ability of future generations to meet their own needs. It contains two key concepts:

1. The concept of "needs", in particular the essential needs of the world's poor, to which overriding priority should be given.

2. The idea of limitations imposed by the state of technology and social organization on the environment ability to meet present and future needs" (Stappen, 2006). Officially, the concept was adopted at the second
"Earth Summit" in 1992 and since then, the sustainable development has been treated as a new, environmentally optimal and socially rewarding vision of the development of the human civilisation (Piontek, 2002; Renouard and Ezvan, 2018).

Together with the dissemination of the concept, it began to be perceived as a global reference to corporate social responsibility used in management at the microeconomic level (Zieliński, 2014; Zutek, 2012). The issues concerning the role of enterprises and their employees in its developments started to be widely studied and described.

Various challenges enterprises are facing nowadays and will face in the future are mentioned as reasons for which they take initiatives connected with the realisation of the idea of sustainable development. They include: the necessity to build the market position by means of focusing on innovativeness, constantly advancing process of internationalisation, the emergence of new technologies and changes in employment connected with them as well as changes on the labour market resulting from the starting period of professional activity of the so called "millennials" (Moczydłowska, 2015; Turner et al., 2018).

These factors, among others, caused the fact that a strategic approach to sustainable development, for companies operating in specific countries and on the international market, has become a key factor in building a competitive advantage and new principles of cooperation with stakeholders, who also include employees (Rodriguez et al., 2002; Cui et al., 2018).

In the research on the impact of sustainable development on the operation of enterprises and their employees, a new trend also appeared. It connected this concept with the theory and practice of human resource management - sustainable human resource management (Ehnert, 2009; Pabian 2011; Pocztowski, 2016). It consists of conduction of all the parts of the human resource process in such a way that the employees could realise company's economic, environmental and social objectives, flexibly adapting it to turbulent changes in the surrounding environment as well as functioning in the conditions of chaos and crisis (Grudzewski et al., 2010), simultaneously contributing to "balancing intergenerational needs" (Pabian, 2015).

In the strategic human resource management (SHMR) implementation, employees' needs cannot be forgotten. They include employee-centred treatment of people in the working process, development of effective systems of work, enhancement of confidence as the base for shaping social relations in the working environment, creation and development of programs allowing reconciliation of work and private life (Robak, 2015), 
as well as healthy work organisation building and learning employees how to take care of their health (Pocztowski et al., 2011). Such understanding of Human Resource Management (HMR) activities has resulted from the changes in the attitude towards people management over the last few decades. In consequence of these changes, people started to be treated as a key factor of the capital regarded as a demanding collective partner and a co-responsible stakeholder and at the same time the main source of diversity in enterprises.

A significant emphasis, regarding sustainable approach to HRM, is also placed on taking natural environment initiatives and on workers' participation in these initiatives by shaping their attitudes and behaviours referred to as "green". Some people even talk about the introduction of the green human resources management (Jackson et al., 2011; Renwick et al., 2013), or building green leadership for green teams allowing for the creation of the organizational culture facilitating workers' engagement in environment protection issues and inclusion of environmental issues in traditional HRM areas (Rajasshrie and Brijesh, 2014).

\section{Material and methods}

If it is assumed that conducting a business activity in compliance with binding and recognised ethical principles, managing diversity policy, environmental requirements and stakeholders' expectations (Turner et al., 2018) and needs constitutes a practical reflection of the adoption of the aides if sustainable development in the company and human resources management, then the search for principles, methods and ways of implementation of these assumptions should be conducted through the analysis of company internal documents, and especially their development strategies, missions and documents with formal principles; that is ethical codes. Such a research procedure was realised in order to gather the information needed to perform empirical analysis the results of which will be presented in the further part of this elaboration. Information achieved in this way was complemented by corporate social responsibility (CSR) reports (Nazari, 2017) and reports of good practices. The presented analysis was based on data and information regarding Warsaw Stock Exchange Index of the twenty largest companies WIG 20 in two periods: mid-2015, i.e. before the entry into force of EU regulations regarding the obligation to report non-financial data for large enterprises, and in mid-2018, i.e. one and a half years after the introduction of these provisions.

\section{Results and discussion}

The surveyed companies were divided into three categories: industrial, service and financial services. In 2015, WIG 20 included: in the group of industrial companies - raw materials: LWB and KGHM; fuel PGNiG and PLN Orlen; chemical: Synthos), in the group of service companies - dealing in retail trade: LPP and Eurocash; operating in the media area: Cyfrowy Polsat; computer science: Asseco; telecommunications: Orange Polska; and energy: ENEA, PGE, ENERGA, TAURON). The third group includes companies from the financial sector, including banks: Alior, PKO BP, PKO SA, BZ WBK, mBank and the insurer, PZU SA.

Among the WIG 20 companies in 2018 were: industrial companies: JSW, KGHM, LOTOS, PGNiG, PKN Orlen), companies conducting commercial and service activities: LPP, Eurocash, CCC, CDProjekt, Cyfrowy Polsat, Orange Polska, ENERGA, PGE, TAURON and financial companies: Alior, PKO BP, PKO SA, BZWBK, mBank; PZU SA.
Based on the analysis of the information presented on the websites of these companies, it can be noticed that the majority of the surveyed companies did not separate and still do not separate activities in the area of CSR and sustainable development. Therefore, one may be in doubt about how important it is for them to implement the CSR concept in comparison to sustainable development; it can be assumed that a smaller importance is attached to the latter. Most of the surveyed companies do not separate the activities in the area of CSR and sustainable development. It can also be believed that the implementation of the idea of sustainable development is not of great significance for them. Only companies of fuel and power sector pay attention to the realisation of this concept and to reporting practices connected with it. It should be stressed, however, that the areas of corporate social responsibility and sustainable development are combined into logical whole and thus provide joint report.

Based on the information presented by the companies on their web pages (table 1 and 2), it is difficult to judge to what extent the principles of sustainability are reflected in HR policy and in HRM and even more, if any actions supporting sustainable HRM are taken. Only a few of them provide information concerning diversity policy or anti-discrimination codes - LPP, Cyfrowy Polsat, BZ WBH and PKO SA. It is clear that some of them do not attach any importance to informing about their attitude to the implementation of sustainable development principles and CSR; it is particularly visible when searching for information on the websites of CDProjekt and Eurocash.

Two of the largest listed companies, namely PGNiG and KGHM deserve special attention. After analysing the information available on their websites and comparing it with the data of Responsible Business Forum, it can be concluded that both companies meet the standards expected by the European Union. In the case of KGHM, the fact that this company has been in GC since 2014 deserves a special attention and PGNiG is the only company that informs about the implementation of AA1000 standard.

In the case of other companies of WIG 20, there is no information indicating the fact that the implementation within the area of CSR or sustainable development is in progress or planned, the more so that the principles of this development introduce HRM into practice.

However, attention should be paid to some activities taken up by companies of power sector, as well as Cyfrowy Polsat and Orange.

Detailed analysis of the activities of power sector companies shows very similar categories of activities. They are connected with their participation in campaigns promoting the development of renewable sources of energy and energy efficiency.

Similar programs are signalled by two other companies, however, in their case, it is a campaign promoting clean natural environment instead of not dumping electronic waste together with household waste.

Consecutively, the activities of LPP arise a lot of controversy, as it is a company that moved most of its production to Bangladesh. Until recently, the company was accused of not having an ethical code binding on all its factories. It was only in 2016 that such a code was adopted.

When comparing information on 2015 and 2018, it is clear that the changes that were made in this period regard a small change in WIG 20 group, while in the actions taken and in activities for the implementation of CSR and sustainable development, such changes can't be seen. The study allows us to state that the managers of the largest Polish companies know the principles of sustainable development and CSR.

Companies in both periods carry out the same activities, so it can be concluded that either all of them implement a long-term strategy or once the program was implemented, it continues without making an effort to 
Table 1. Sustainable development reflected in the information on company websites in 2015

\begin{tabular}{|c|c|c|c|c|}
\hline Company & A tab on the homepage & Distinguishing activities & Ethical codes & RI membership \\
\hline LWB Bogdanka & yes, in 2017 & $\begin{array}{l}\text { The Solidarity Miners Foundation } \\
\text { (Fundacja Solidarni Górnicy) }\end{array}$ & yes, in 2013 & yes \\
\hline KGHM & deficiency & $\begin{array}{l}\text { KGHM Foundation; } \\
\text { Global Compact Membership }\end{array}$ & in preparation & yes \\
\hline PGNIG & yes, in 2015 & $\begin{array}{l}\text { CSR reports on the basis of GRI; } \\
\text { standard AA1000; PGNIG Foundation }\end{array}$ & yes, in 2009 & yes \\
\hline PKN Orlen & yes, in 2017 & Orlen Dar Serca Foundation & yes, in 2012 & yes \\
\hline Synthos Oświęcim & deficiency & $\begin{array}{l}\text { A golden card of safe work leader } \\
\text { (Złota Karta Lidera Bezpiecznej Pracy) }\end{array}$ & yes, no full version and date of admission & lack of information \\
\hline LPP & yes & $\begin{array}{l}\text { Support, among others, for: Fundacji Hospicyjnej } \\
\text { in Gdańsk Caritas Polska }\end{array}$ & yes, Anti-corruption Code in 2015 & lack of information \\
\hline Erocash & deficiency & $\begin{array}{l}\text { Support, among others, for: PCK Przemyśl, } \\
\text { Enigma Foundation }\end{array}$ & $\begin{array}{l}\text { lack of data on the website; } \\
\text { on the web: Eurocash Licensed Clubs Code }\end{array}$ & lack of information \\
\hline Cyfrowy Polsat & yes & Polsat Foundation & lack of data on the website & yes \\
\hline Orange PL & yes, in 2015 & Orange Foundation & yes, in 2014 & yes \\
\hline Assecpol Rzeszów & deficiency & $\begin{array}{l}\text { Support for foundations: "Mimo wszystko", } \\
\text { TVN “Nie jesteś sam" }\end{array}$ & lack of data on the website & lack of information \\
\hline Enea & yes & $\begin{array}{l}\text { Investments in the development of renewable } \\
\text { energy sources and energy sources from CHP, } \\
\text { the ENEA Foundation, }\end{array}$ & yes, in 2013 & yes \\
\hline Energa SA & yes & "ENERGA for Environment" Program & yes, in 2014 & yes \\
\hline PGE SA & yes & PGE "Energia z serca" Foundation & yes, in 2011 & yes \\
\hline $\begin{array}{l}\text { Tauron Polska } \\
\text { Energia SA }\end{array}$ & yes & TAURON Foundation, & yes & yes \\
\hline Alior Bank & deficiency & lack of information & Lack of data on the website & lack of information \\
\hline mBank & deficiency & mBank Foundation & Lack of data on the website & lack of information \\
\hline Pekao SA & yes & Marian Kanton's PEKAO S.A. BANK Foundation & $\begin{array}{l}\text { Code of Banking Ethics of the Association of Polish Banks; } \\
\text { Good Practices in Financial Market Canon; UniCredit Group } \\
\text { Charter of Good Conduct Rules; Declaration of Equal } \\
\text { Opportunities and Anti-Discrimination }\end{array}$ & lack of information \\
\hline \multirow[t]{2}{*}{ PKO BP } & deficiency & PKO Bank Polski Foundation; & $\begin{array}{l}\text { Code of Banking Ethics of the Association of Polish Banks; } \\
\text { Good practices of WSE companies }\end{array}$ & lack of information \\
\hline & & "Eco office" project & & \\
\hline PZU SA & yes & PZU Foundation & Principles of Good Insurance Practices, Good PZU Practices & yes \\
\hline
\end{tabular}

Source: author's own elaboration on the basis of information from company websites; and: Czarnecka and Zadros, 2015

take new initiatives. It can't be said which of these statements is true without conducting further, in-depth studies.

Companies, even the largest ones, are presently at different stages of implementation and monitoring of approved corporate social responsibility practices and to impose a standardization of reporting procedures on them may increase their operating costs without the expected social and environmental effect. How big the problems with the implementation of sustainability reporting based on the RESPECT Index are shows the analysis conducted on the 20 largest Polish listed companies, and it can be assumed that in the case of smaller firms, the problems associated with it will be even bigger. Such a situation probably concerns not only Polish companies, but most companies operating in European Union countries as well.

Besides, one can't look at the activities in the area of CSR in the surveyed companies only from a positive perspective. It should be clearly noted that not all companies implement the CSR strategy sufficiently to be included in the RESPECT Index. However, as the results of the "Responsible Business Report in Poland. Good practices" (Odpowiedzialny, 2015) show, many much smaller companies show much more socially responsible initiatives and occupy much higher positions in the rankings than the largest and strongest listed companies in Poland.

\section{Conclusion}

Despite a very limited number of samples which took part in the research, it can be concluded that the executives managing the largest Polish companies are acquainted with the principles of sustainable development. They are also aware of their impact on the realisation of the personnel function and HRM that take into account the guidelines of this development. What is more, their views on SHRM realisation are similar to the ones presented by 
Table 2 Sustainable development reflected in the information on company websites in 2018

\begin{tabular}{|c|c|c|c|c|}
\hline Company & A tab on the homepage & Distinguishing activities & Ethical codes & RI membership \\
\hline JSW & responsible business & Academy of Talents (Akademia Talentów) & yes & yes \\
\hline KGHM & yes & $\begin{array}{l}\text { KGHM Foundation; Global Compact } \\
\text { Membership }\end{array}$ & yes & yes \\
\hline PGNIG & no, access through ABOUT PGNIG tab & $\begin{array}{l}\text { CSR reports on the basis of GRI; standard } \\
\text { AA1000; PGNIG Foundation }\end{array}$ & yes & yes \\
\hline PKN Orlen & yes & Orlen Dar Serca Foundation & yes & yes \\
\hline LOTOS & responsible LOTOS & $\begin{array}{l}\text { Złota Karta Lidera Bezpiecznej Pracy (A } \\
\text { golden card of safe work leader) }\end{array}$ & yes & $\begin{array}{l}\text { yes, no confirmation on } \\
\text { WSE website }\end{array}$ \\
\hline LPP & responsibility & $\begin{array}{l}\text { Support, among others, for: Fundacii } \\
\text { Hospicyjnej w Gdańsku Caritas Polska }\end{array}$ & yes, Anti-corruption Code & no \\
\hline Erocash & no & $\begin{array}{l}\text { Support, among others, for: PCK Przemyśl, } \\
\text { Enigma Foundation }\end{array}$ & Lack of data on the website & no \\
\hline Cyfrowy Polsat & $\begin{array}{l}\text { no, access through Relations with } \\
\text { Investors tab }\end{array}$ & Polsat Foundation & Principles of Good Practices; Diversity Policy & no \\
\hline Orange PL & no, access through About us tab & Orange Foundation & yes; Good Practices Code & yes \\
\hline ccc & $\begin{array}{l}\text { no, access through About company, } \\
\text { Relations with investor tabs }\end{array}$ & $\begin{array}{l}\text { Support for foundations:"A kogo","Mimo } \\
\text { wszystko", TVN“Nie jesteś sam" }\end{array}$ & Good Practices & no \\
\hline CD Projekt & no tabs & Lack of information & Lack of data on the website & no \\
\hline Enea & yes & $\begin{array}{l}\text { Support for foundations: "A kogo","Mimo } \\
\text { wszystko", TVN “Nie jesteś sam" }\end{array}$ & yes & yes \\
\hline Energa SA & yes & "ENERGA for Environment" Program & yes & yes \\
\hline PGE SA & yes & PGE "Energia z serca“ Foundation & yes & yes \\
\hline Tauron SA & yes & TAURON Foundation, & yes & yes \\
\hline Alior Bank & no tabs & Lack of data & lack of data on the website & no \\
\hline BZWBK SA & $\begin{array}{l}\text { no, access through Information about } \\
\text { bank tab }\end{array}$ & $\begin{array}{c}\text { Stefan Bryła's Bank Zachodni WBK } \\
\text { Foundation }\end{array}$ & $\begin{array}{l}\text { General Code of Proceedings; Anti-corruption } \\
\text { Program }\end{array}$ & yes \\
\hline mBank & no tabs & mBank Foundation & Lack of data on the website & yes \\
\hline Pekao SA & $\begin{array}{l}\text { no, access through About bank, Social } \\
\text { responsibility tab }\end{array}$ & $\begin{array}{c}\text { Marian Kanton's PEKAOS.A. BANK } \\
\text { Foundation }\end{array}$ & $\begin{array}{l}\text { Code of Banking Ethics of the Association of Polish } \\
\text { Banks; Good Practices in Financial Market Canon; } \\
\text { UniCredit Group Charter of Good Conduct Rules; } \\
\text { Declaration of Equal Opportunities and Anti- } \\
\text { Discrimination }\end{array}$ & no \\
\hline PKO BP & lack of information & PKO Bank Polski Foundation & $\begin{array}{l}\text { Code of Banking Ethics of the Association of Polish } \\
\text { Banks; Good practices of WSE companies }\end{array}$ & no \\
\hline PZUSA & no, Social responsibility & PZU Foundation & $\begin{array}{c}\text { Principles of Good Insurance Practices, Good PZU } \\
\text { Practices }\end{array}$ & yes \\
\hline
\end{tabular}

Source: author's own elaboration on the basis of information from company websites

foreign corporation representatives and they take into account national and international scientific achievements.

For a more detailed examination of this issue, it is necessary to deepen the research conducted by the author and to carry out other analyses regarding these issues. Due to the scant research sample, the statement that the aim of this paper was achieved is highly uncertain. However, it is possible to make a preliminary statement that WIG 20 companies implement principles of sustainable development and take efforts to promote employees' participation in its realisation.

The changes in the attitude to HRM can also be noticed and positively assessed. They help companies get prepared to compete for achievement of market advantage by cooperating with employees who are perceived as stakeholders contributing to the creation of relations with the environment and not only as an element of resources inevitable in the realisation of aims.

\section{References}

CZARNECKA, A. - ZADROS, K. 2015. Społeczna odpowiedzialność jako element nowoczesnego zarządzania organizacjami gospodarczymi. In Bazan-Bulana, A. Robak, E. -Kwiatek, A. (ed.). Udział pracowników w zarządzaniu nowoczesnymi organizacjami gospodarczymi. Wydawnictwo Wydziału Zarządzania Politechniki Częstochowskiej, 2015, pp. 122-135

CUI, J. - JO, H. - NA, H. 2018. Does Corporate Social Responsibility Affect Information Asymmetry? In Journal Bus Ethics, 2018, no. 148, pp. 549-572.

EHNERT, I. 2009. Sustainable Human Resource Management. A Conceptual and Exploratory Analysis from a Paradox Perspective. New York : Physica-Verlag A Springer Company, 2009.

GRUDZEWSKI, W.M. - HEJDUK, I.K. (ed.) 2002. Przedsiębiorstwo przyszłości - wizja strategiczna. Warszawa : Difin, 2002.

HAHN, T. - FIGGE, F. - PINKSE, J. - PREISS, L. 2018. A Paradox Perspective on Corporate Sustainability: Descriptive, Instrumental, and Normative Aspects. In Journal Bus Ethics, 2018, no. 148, pp. 235-248.

JACKSON, S.E. - RENWICK, W.S. - JABBOUR, C.J.C. - MULLER-CAMEN, M. 2011. State-ofthe-Art and Future Directions for Green Human Resource Management: Introduction 
to the Special Issue. In Zeitschrift für Personalforschung, vol. 25, 2011, no. 2, pp. 99-116.

MOCZYDłOWSKA, J.M. 2015. Koncepcja "Przedsiębiorstwa przyszłości“ jako źródło nowych paradygmatów w obszarze zarządzania kapitałem ludzkimi. In Zeszyty Naukowe Wyższej Szkoły Handlowej Zarządzanie, 2015, no. 2, pp. 27-36.

NAZARI, J.A. - HRAZDIL, K. - MAHMOUDIAN, F. 2017. Assessing social and environmental performance through narrative complexity in CSR reports. I Journal of Contemporary Accounting \& Economist", 2017, no. 13, pp. 166-178.

ODPOWIEDZIALNY BIZNES W POLSCE. Dobre Praktyki. 2015. Raport Forum Odpowiedzialnego Biznesu, (lack authors), Warszawa, 2015.

PABIAN, A. 2011. Sustainable personel - pracownicy przedsiębiorstwa przyszłości. In Zarządzanie Zasobami Ludzkimi, 2011, no. 5, pp. 9-18.

PABIAN, A. 2015. Zrównoważone zarządzanie zasobami ludzkimi - zarys problematyki. In Zeszyty Naukowe Politechniki Częstochowskiej, Zarzadzanie, 2015, no. 17, pp. 7-16.

PIONTEK, B. 2002. Koncepcja rozwoju zrównoważonego i trwałego Polski. Warszawa : PWN, 2002.

PŁACZEK, E. 2012. Zrównoważony rozwój - nowym wyzwaniem dla wspótczesnych operatorów logistycznych. In Prace Naukowe Politechniki Warszawskiej, Transport, 2012, no. 84, pp. 79-92.

POCZTOWSKI, A. 2016. Zrównoważone zarządzanie zasobami ludzkimi w teorii i praktyce. In Zarządzanie i Finanse, Journal of Management and Finance, vol. 14, 2016, no. 2/1, pp. 303-314

POCZTOWSKI, A. (ed.) 2011. Human Resource Management in Transition. Warszawa : The Polish Case, Wolters Kluwer business.

RAJASSHRIE, P. -, BRIJESH, S. 2014. Green Human Resources Management. In International Journal of Multidisciplinary Reaserch, vol. 4, 2014, no. 1, p. 72-82.

RENOUARD, C. - EZVAN, C. 2018. Corporate social responsibility towards human development: A capabilities framework. In Business Ethics A European Review, vol. 27, 2018, no. 2, pp. 144-155.

RENWICK, D. - REDMAN, T. - MAGUIRE, S. 2013. Grenn Human Resources Management: Review and Research Agenda. In International Journal of Management Review, vol. 15, 2013, no. 1, pp. 1-14.
ROBAK, E. 2015. Uwarunkowania i zagrożenia związane z czasem pracy w opiniach pracowników. In Humanizacja Pracy, 2015, no. 1 (279), pp. 271-283.

RODRIGUEZ, M.A. - RICART, J.E. - SANCHEZ, P. 2002. Sustainable Development and the Sustainability of Competitive Advantage: A Dynamic and Sustainable View of the Firm. In Sustainable Development and Competitive Advantage, vol. 11, 2002, no. 3, pp. 135-146.

STAPPEN, R.K. 2006. Der Wise Consensus - Die Voraussetzung für nachhaltige Entscheidungen und Problemlösungen im 21. Jahrhundert. www.ias-icsd.org (access: 5.04.2018).

TURNER, M.R. - MCINTOSH, T. - REID, S.W. - BUCKLEY, M.R. 2018. Corporate implementation of socially controversial CSR initiatives: Implications for human resources management. In Human Resource Management Review, 2018, pp. 1-12.

ZIELIŃSKI, M. 2014. Korzyści z wdrożenia koncepcji CSR w zarządzaniu zasobami ludzkimi. In Zeszyty Naukowe Politechniki Śląskiej, Organizacja i Zarzadzanie, 2014, no. 74, pp. 654-663.

ZUTEK, D.K. 2010. Społeczna odpowiedzialność biznesu a zrównoważony rozwój przedsiębiorstw. In Zeszyty Naukowe Małopolskiej Wyższej Szkoły Ekonomicznej w Tarnowie, vol. 21, 2010, no. 2, pp. 198-207.

\section{Contact address}

Katarzyna Zadros Ph.D., Częstochowa University of Technology, Faculty of Management; phone: (48) 343250422 al. Armii Krajowej 36b 42-201 Częstochowa, Poland, e-mail: katarzyna.zadros@wz.pcz.pl 